\title{
UPAYA MENINGKATKAN HASIL BELAJAR MATEMATIKA SISWA SMA MELALUI MODEL PEMBELAJARAN KOOPERATIF TIPE SNOWBALL THROWING
}

\author{
Zahara \\ SMA Negeri 18 Palembang \\ zahara@gmail.com
}

\begin{abstract}
ABSTRAK
Penelitian ini bertujuan mengumpulkan dan menganalisis data tentang upaya meningkatkan hasil belajar matematika melalui model pembelajaran kooperatif tipe Snowball Throwing pada kelas XII IPA 3 SMA Negeri 18 Palembang. Penelitian ini menggunakan penelitian tindakan kelas (classroom action research) sebanyak dua siklus. Setiap siklus terdiri dari empat tahap, yaitu : rancangan, kegiatan dan pengamatan, refleksi, dan revisi. Subjek penelitian ini adalah siswa kelas XII IPA 3 SMA Negeri 18 Palembang Tahun Pelajaran 2015/2016. Dari hasil analisis didapatkan bahwa hasil belajar siswa mengalami peningkatan dari pra siklus, siklus I sampai siklus II, yaitu pra siklus $(42,11 \%)$, siklus I $(68,42 \%)$, siklus II $(86,84 \%)$. Simpulan dari penelitian ini adalah model pembelajaran kooperatif tipe Snowball Throwing dapat berpengaruh positif terhadap hasil belajar peserta didik Kelas XII IPA 3 SMA Negeri 18 Palembang, serta model pembelajaran ini dapat digunakan sebagai salah satu alternatif pembelajaran matematika.
\end{abstract}

Kata kunci : Hasil belajar, matematika, Snowball Throwing

\begin{abstract}
This study aims to collect and analyze data about efforts to improve mathematics learning outcomes through the Snowball Throwing cooperative learning model in class XII Science 3 of SMA Negeri 18 Palembang. This study uses classroom action research as much as two cycles. Each cycle consists of four stages, namely: design, activity and observation, reflection, and revision. The subjects of this study were students of class XII Science 3 of SMA Negeri 18 Palembang in the 2015/2016 Academic Year. From the results of the analysis found that student learning outcomes have increased from pre-cycle, cycle I to cycle II, namely pre-cycle $(42.11 \%)$, cycle I $(68.42 \%)$, and cycle II $(86.84 \%)$. The conclusion of this research is the Snowball Throwing cooperative learning model can positively influence the learning outcomes of Class XII Science 3 students of SMA Negeri 18 Palembang, and this learning model can be used as an alternative to mathematics learning.
\end{abstract}

Keywords : Learning outcomes, mathematics, Snowball Throwing 


\section{PENDAHULUAN}

Setiap warga negara berhak mendapat pendidikan (UUD 45 pasal 31 ayat), hal ini akibat logis dari dasar negara yaitu pancasila yang dianut oleh bangsa Indonesia. Menurut Undang-undang Sistem Pendidikan Nasional (UUSPN) No. 20/2003 pendidikan untuk mencerdaskan anak bangsa. Tujuan pendidikan nasional di Indonesia membentuk manusia Indonesia seutuhnya agar tercipta sumber daya manusia Indonesia yang bertaqwa kepada Tuhan Yang Maha Esa, cerdas, berkualitas dan bermartabat. Implementasi KTSP dalam pembelajaran yang efektif dan menyenangkan menuntut guru untuk lebih sabar, penuh perhatian dan pengertian serta mempunyai kreativitas dan penuh dedikasi untuk menumbuhkan rasa percaya diri siswa. Dalam penyusunan rencana pelaksanaan pembelajaran, guru harus mampu merancang instruksi yang harmonis antar komponen sistem pembelajaran sehingga pembelajaran berlangsung dalam suasana fun, demokratis dan menyenangkan (Mulyasa, 2005:5).

Menurut Hamalik (2007:27) belajar merupakan suatu proses, suatu kegiatan dan bukan suatu hasil atau tujuan. Belajar bukan hanya mengingat, tetapi mengalami. Hasil belajar bukan hanya suatu penguasaan hasil latihan melainkan pengubahan kelakuan. Hal ini berarti belajar merupakan proses dimana anak menerima pelajaran dari tidak bisa menjadi memiliki kemampuan setelah dia belajar.

Pembelajaran ialah membelajarkan siswa menggunakan asas pendidikan maupun teori belajar merupakan penentuan utama keberhasilan pendidikan. Pembelajaran merupakan proses komunikasi dua arah, mengajar dilakukan oleh pihak guru sebagai pendidik, sedangkan belajar dilakukan oleh murid (Sagala, 2010:61). Menurut Uno (2007:54) pembelajaran adalah suatu proses interaksi antara peserta belajar dengan pengajar dan sumber pengajar pada suatu lingkungan belajar untuk mencapai tujuan belajar tertentu.

Sistem pengajaran yang sering dilakukan dalam pengajaran matematika selama ini yaitu guru menjelaskan pelajaran, sedangkan siswa mendengarkan, lalu guru memberikan contoh soal, kemudian meminta siswa untuk mengerjakan soal-soal lainnya. Hal ini belum mendapatkan hasil yang maksimal. Berbagai usaha telah dilakukan oleh guru misalnya menggunakan metode tanya jawab, dan ceramah.

Hasil belajar siswa pada mata pelajaran matematika dengan KKM 75, dengan daya serap tuntas yang diharapkan $75 \%$, dari 38 siswa. Hanya 14 siswa yang memenuhi standar KKM dengan daya serap secara klasikal 37\%. Melihat kondisi ini dicoba menggunakan model pembelajaran kooperatif yaitu model pembelajaran kooperatif tipe Snowball Throwing. Diharapkan dengan model pembelajaran kooperatif tipe Snowball Throwing ini dapat membuat siswa lebih termotivasi dan aktif dalam pembelajaran matematika dan pada akhirnya dapat meningkatkan hasil belajar mereka.

Pembelajaran kooperatif adalah sebuah kelompok strategi pengajaran yang melibatkan siswa bekerja secara berkolaborasi untuk mencapai tujuan bersama. Menurut Ibrahim (2000) belajar kooperatif dapat mengembangkan tingkah laku kooperatif dan hubungan yang lebih baik antar siswa dan dapat mengembangkan kemampuan akademis siswa. Menurut Bayor (Hidayanto, 2006) Snowball Throwing adalah salah satu model pembelajaran aktif yang pelaksanaannya banyak melibatkan siswa. Model pembelajaran kooperatif tipe Snowball Throwing adalah model pembelajaran yang diawali dengan membentuk kelompok. Siswa mendapat tugas 
dari guru untuk membuat pertanyaan yang dibentuk bola dan dilemparkan kepada siswa lain. Siswa yang menerima bola menjawab pertanyaan tersebut.

Langkah-langkah model pembelajaran kooperatif tipe Snowball Throwing menurut Suprijono (2011: 128) adalah sebagai berikut: 1) Guru menyampaikan materi yang akan disajikan, 2) Guru membentuk kelompok-kelompok dan memanggil ketua kelompok untuk diberi penjelasan tentang materi, 3) Masingmasing ketua kelompok kembali ke kelompoknya masing-masing dan menyampaikan materi dari guru kepada temannya, 4) Kemudian masing-masing siswa diberi kertas untuk menulis satu pertanyaan yang menyangkut materi yang sudah dijelaskan oleh ketua kelompok, 5) Kemudian kertas tersebut dibentuk seperti bola dan dilemparkan kepada siswa lainnya selama \pm 15 menit, dan 6) Peseta didik yang mendapat bola diberi kesempatan untuk menjawab pertanyaan yang tertulis pada bola secara bergantian.

Menurut Sudjana (2009) hasil belajar adalah kemampuan-kemampuan yang dimiliki siswa setelah ia menerima pengalaman belajarnya yakni keterampilan dan kebiasaan, pengetahuan dan pengertian, sikap dan cita-cita. Kemampuan kognitif, afektif maupun psikomotorik dapat dikuasai dari proses belajar mengajar. Kunandar (2013) mengatakan bahwa hasil belajar adalah kompetensi atau kemampuan tertentu baik kognitif, afektif maupun psikomotorik yang dicapai atau dikuasai siswa setelah mengikuti proses belajar-mengajar.

Perubahan tingkah laku dapat berupa perubahan terhadap pengetahuan, sikap dan keterampilan. Disamping terjadinya perubahan tingkah laku, banyak hal lain yang didapatkan dari belajar tersebut diantaranya seseorang dapat memperoleh kecakapan, mendapatkan keterampilan dan menentukan suatu sikap. Namun semuanya itu bukanlah disebabkan oleh karena adanya proses kematangan.

Menurut Purwanto (2011) hasil belajar dapat didefinisikan dan dapat dipahami dengan dua kata yang membentuknya yaitu "hasil" dan "belajar" pengertian hasil belajar menunjukkan pada suatu perolehan akibat dilakukannya suatu aktivitas atau suatu proses yang mengakibatkan berubahnya input secara fungsional.

Penelitian ini bertujuan untuk meningkatkan hasil belajar matematika siswa melalui model pembelajaran kooperatif tipe Snowball Throwing pada kelas XII IPA 3 SMA Negeri 18 Palembang.

\section{METODE}

Penelitian ini merupakan penelitian tindakan kelas (classroom action research), karena penelitian dilakukan untuk memecahkan masalah pembelajaran di kelas. Penelitian ini juga termasuk penelitian deskriptif, sebab menggambarkan bagaimana suatu teknik pembelajaran diterapkan dan bagaimana hasil yang diinginkan dapat dicapai.

Penelitian ini mengacu pada perbaikan pembelajaran yang berkesinambungan. Kemmis dan Taggart (1988:14) menyatakan bahwa model penelitian tindakan adalah berbentuk spiral. Tahapan penelitian tindakan pada suatu siklus meliputi perencanaan, pelaksanaan, observasi, dan refleksi. Siklus ini berlanjut dan akan dihentikan jika sesuai dengan kebutuhan dan dianggap sudah cukup.

Penelitian dilaksanakan di SMA Negeri 18 Palembang tahun pelajaran 2015/2016. Penelitian dilakukan di kelas XII IPA 3 tempat dilaksanakannya pembelajaran matematika selama ini. Subjek penelitian sebanyak 38 siswa. 
Penelitian dilaksanakan selama dua bulan yaitu Februari-Maret 2016 semester genap tahun pelajaran 2015/2016.

Indikator keberhasilan penelitian ini dengan menggunakan hasil nilai pembelajaran KKM $75 \%$ dan telah terjadinya peningkatan hasil belajar siswa terhadap pelajaran Matematika.

Penelitian ini dilakukan melalui tiga tahap, yaitu: (1) tahap persiapan, kegiatan yang dilakukan dalam tahap persiapan ini adalah mempersiapkan segala sesuatu yang berhubungan dengan pelaksanaan penelitian. Dalam kegiatan ini diharapkan pelaksanaan penelitian akan berjalan lancar dan mencapai tujuan yang diinginkan. Kegiatan persiapan ini meliputi: kajian pustaka, penyusunan rancangan penelitian, orientasi lapangan, dan penyusunan instrumen penelitian. (2) tahap pelaksanaan, pada tahap ini, kegiatan yang dilakukan meliputi: pengumpulan data melalui tes dan pengamatan yang dilakukan persiklus, diskusi dengan pengamat untuk memecahkan kekurangan dan kelemahan selama proses belajar mengajar persiklus, menganalisis data hasil penelitian persiklus, menafsirkan hasil analisis data, dan bersama-sama dengan pengamat menentukan langkah perbaikan untuk siklus berikutnya, dan (3) tahap penyelesaian yang meliputi: menyusun draf laporan penelitian, mengkonsultasikan draf laporan penelitian, merevisi draf laporan penelitian, menyusun naskah laporan penelitian, dan menggandakan laporan penelitian.

\section{HASIL DAN PEMBAHASAN}

\section{Pra Siklus}

Kegiatan pada pra siklus, pembelajaran dilaksanakan dengan menggunakan metode ceramah yang diakhiri dengan pelaksanaan tes. Hasil proses pembelajaran terlihat monoton dan berpusat pada guru, sehingga dampak hasil belajar siswa rendah, dengan dibuktikan hasil tes. Ketuntasan belajar hanya mencapai 42,11\%. Pembelajaran yang dilakukan sebelumnya belum memberikan hasil yang maksimal.

\section{Siklus I}

Siklus pertama dilaksanakan dalam dua kali pertemuan atau dua kali tatap muka, dengan lama waktu 2 jam pelajaran yaitu 90 menit untuk satu kali pertemuan. Tahapannya yaitu :

a) Perencanaan

Setelah data hasil belajar siswa dikumpulkan, lalu ditentukan tindakan-tindakan yang perlu dilakukan agar dapat meningkatkan hasil belajar siswa, menyusun Rencana Pelaksanaan Pembelajaran (RPP) yang digunakan pada siklus pertama dengan kompetensi dasar: konsep transformasi geometri, mempersiapkan materi ajar yang akan disampaikan kepada siswa, mempersiapkan bahan untuk diskusi kelompok siswa, dan menyusun soal-soal tes untuk menilai hasil belajar siswa.

b) Tindakan

Siklus pertama ini dilakukan ketika jam 1-2 di kelas XII.IPA.3 diawali guru masuk ke kelas, memberi salam kepada siswa, memperhatikan kehadiran siswa, memberikan penjelasan singkat kepada siswa tentang model pembelajaran yang akan digunakan. Setelah semua siswa paham mengenai teknis pelaksanaan model pembelajaran kooperatif tipe snowball throwing, lalu kegiatan pembelajaran dimulai dengan menyampaikan tujuan pembelajaran. Selanjutnya pembelajaran dimulai dengan melakukan apersepsi dengan memberikan beberapa pertanyaan. 
Dilanjutkan guru memotivasi siswa untuk mengusai materi yang akan dibahas dan menyampaikan adanya keterkaitan materi yang akan dipelajari dengan kehidupan sehari-hari.

Pada tahap kegitan inti, guru membentuk kelompok dan memanggil ketua kelompok untuk memberi penjelasan tentang konsep transformasi geometri, masing-masing ketua kelompok kembali ke kelompoknya kemudian menjelaskan materi yang disampaikan oleh guru kepada teman di dalam kelompoknya. Kemudian masing-masing siswa diberikan satu lembar kerja untuk menuliskan pertanyaan apa saja yang menyangkut materi yang sudah dijelaskan oleh ketua kelompok. Siswa bekerja dengan sesama kelompoknya. Setelah itu siswa diminta menuliskan satu pertanyaan di kertas. Kertas itu dibentuk seperti bola dan dilemparkan pada siswa lainnya dari kelompok lain. Siswa yang menerima lemparan bola diwajibkan untuk menjawab pertanyaan yang tertera di dalamnya. Kalau tidak bisa menjawab, maka dibantu oleh temannya satu kelompok.

c) Observasi

Observasi dilakukan oleh teman sejawat dari guru yang mengadakan penelitian. Teman sejawat tersebut diminta untuk mengamati kegiatan yang dilakukan siswa ketika masa penelitian tersebut. Siswa mengikuti pembelajaran dengan cukup aktif. Walaupun belum terlalu siap, mereka dengan antusias membuat pertanyaan yang diminta guru. Ketika mereka mendapat bola, mereka pun dengan antusias juga untuk menjawabnya, walaupun terkadang jawabannya salah. Ketua-ketua kelompok yang diberi tugas untuk menyampaikan materi pada kelompoknya juga berperan sebagaimana mestinya, walaupun mereka belum dapat menyampaikan materi dengan baik. Pembelajaran berlangsung sesuai dengan rencana yang telah ditetapkan.

d). Refleksi

Berdasarkan analisis hasil tes dari 38 orang siswa diperoleh nilai rata-rata tes formatif 1 sebesar 74,08. Siswa yang telah mencapai atau memenuhi KKM sebanyak 26 orang dan yang belum memenuhi KKM sebanyak 12 orang. Dengan demikian, secara klasikal ketuntasan belajar yang telah tercapai sebesar 68,42 \%, artinya secara klasikal termasuk belum tuntas atau belum berhasil.

Hasil tersebut menunjukkan bahwa pada siklus pertama secara klasikal siswa belum tuntas belajar, karena siswa yang memperoleh nilai $\geq 75$ hanya sebesar $68,42 \%$ lebih kecil dari persentase ketuntasan yang dikehendaki yaitu sebesar $85 \%$. Jika diperhatikan, penyebabnya karena siswa masih belum siap membuat pertanyaan dan belum mampu menjawab pertanyaan dengan benar, apalagi materi transformasi geometri termasuk materi yang cukup sulit bagi mereka.

Dari siklus pertama ini ditemukan beberapa kekurangan : 1) masih banyak siswa yang belum mampu dengan sigap mengikuti permainan, apalagi membuat pertanyaan, 2) masih banyak siswa yang merasa takut ketika menerima bola, karena takut tidak bisa menjawab, 3) masih banyak siswa yang hanya mengandalkan temannya untuk menjawab pertanyaan. Dari kekurangankekurangan tersebut maka dilakukan perbaikan-perbaikan dalam melaksanakan tindakan pada siklus selanjutnya seperti : 1) memotivasi dan membantu siswa agar mampu membuat pertanyaan, 2) memotivasi siswa untuk berusaha menjawab pertanyaan yang ditujukan padanya, 3) memotivasi siswa agar bertanggung jawab dengan tugasnya. 


\section{Siklus II}

Siklus kedua dilaksanakan dalam tiga kali pertemuan atau tiga kali tatap muka, dengan lama waktu 2 jam pelajaran yaitu 90 menit untuk satu kali pertemuannya. Tindakan yang dilakukan pada siklus II berupa upaya pembenahan terhadap kekurangan pada siklus I. Langkah-langkah umumnya seperti juga yang dilakukan pada siklus I.

a) Perencanaan

Mempersiapkan bahan ajar yang akan digunakan, menyusun Rencana Pelaksanaan Pembelajaran (RPP) yang digunakan pada siklus kedua, mempersiapkan bahan untuk diskusi kelompok siswa, dan menyusun soal-soal tes untuk menilai hasil belajar siswa.

b) Tindakan

Kegiatan yang dilakukan tetap sama dengan kegiatan pada siklus I. Guru membentuk kelompok dan memanggil ketua kelompok untuk memberi penjelasan tentang lanjutan konsep transformasi geometri, masing-masing ketua kelompok kembali ke kelompoknya kemudian menjelaskan materi yang disampaikan oleh guru kepada teman di dalam kelompoknya. Kemudian masingmasing siswa diberikan satu lembar kerja untuk menuliskan pertanyaan apa saja yang menyangkut materi yang sudah dijelaskan oleh ketua kelompok. Siswa bekerja dengan sesama kelompoknya. Setelah itu siswa diminta menuliskan satu pertanyaan di kertas. Kertas itu dibentuk seperti bola dan dilemparkan pada siswa lainnya dari kelompok lain. Siswa yang menerima lemparan bola diwajibkan untuk menjawab pertanyaan yang tertera di dalamnya. Kalau tidak bisa menjawab, maka dapat dibantu oleh temannya satu kelompok.

Tindakan yang dilakukan pada siklus kedua ini berupa penekanan pada perbaikan atas kekurangan dari siklus pertama tadi. Untuk mengatasi masih banyak siswa yang belum mampu dengan sigap mengikuti permainan, apalagi membuat pertanyaan, maka guru mengajak siswa untuk ikut serta secara penuh dalam permainan, lalu memberikan semangat pada siswa untuk membuat pertanyaan yang sesuai dengan materi dan sesuai tingkat kemampuan mereka. Untuk mengatasi masih banyak siswa yang merasa takut ketika menerima bola, karena takut tidak bisa menjawab, maka guru memberikan pancingan jawaban yang menuju pada terbukanya wawasan siswa terhadap materi. Untuk mengatasi masih banyak siswa yang hanya mengandalkan temannya untuk menjawab pertanyaan, maka guru memotivasi siswa agar bertanggung jawab dengan tugasnya, siswa dibiasakan untuk menjawab dan tidak lari dari masalah.

c) Observasi

Guru telah berusaha membenahi kekurangan pembelajaran. Siswa juga telah berupaya mengikuti pembelajaran dengan lebih aktif. Mereka makin antusias membuat pertanyaan yang diminta guru. Pertanyaan yang dibuat sudah cukup baik dibandingkan sebelumnya. Saat mereka mendapat bola, mereka pun dengan antusias juga untuk menjawab pertanyaan yang terdapat di dalamnya, jawaban yang salah pun makin berkurang. Ketua-ketua kelompok yang diberi tugas makin mahir menyampaikan materi pada kelompoknya, mereka telah dapat menyampaikan materi dengan lebih baik dari sebelumnya, walaupun belum mencapai sempurna. Pembelajaran berlangsung sesuai dengan rencana yang telah ditetapkan guru. 
d) Refleksi

Berdasarkan hasil tes formatif 2 dari 38 orang siswa diperoleh nilai rata-rata sebesar 80,78 . Siswa yang telah mencapai atau memenuhi KKM sebanyak 33 orang dan yang belum memenuhi KKM sebanyak 5 orang. Maka secara klasikal ketuntasan belajar yang telah tercapai sebesar $86.84 \%$ atau dapat dikatakan secara klasikal, pembelajaran telah tuntas atau telah berhasil. Pada siklus ini ada peningkatan ketuntasan belajar secara klasikal dari siklus I dan II sebesar $13,04 \%$.

Adanya peningkatan hasil belajar pada siklus II ini dipengaruhi oleh adanya peningkatan keinginan siswa dalam mempelajari dan menguasai materi pelajaran melalui model pembelajaran Snowball Throwing ini, disamping itu juga dipengaruhi oleh kemampuan guru dalam mengelola proses belajar-mengajar selama kegiatan pembelajaran berlangsung.

Kekurangan pada siklus I telah diperbaiki sehingga : 1) siswa sudah cukup mahir mengikuti permainan, dan juga mampu membuat pertanyaan, 2) siswa yang merasa takut ketika menerima bola, karena takut tidak bisa menjawab, sudah berkurang, 3) banyak siswa yang berusaha menjawab pertanyaan.

Hasil dari penelitian tindakan kelas dengan menerapkan model pembelajaran Snowball Throwing ini, disajikan pada tabel 1 berikut ini.

Tabel 1. Hasil tes formatif pada siklus I dan II

\begin{tabular}{lccl}
\hline & Siklus I & Siklus II & \multicolumn{1}{c}{ Keterangan } \\
\hline Jumlah siswa yang tuntas & 26 siswa & 33 siswa & $\begin{array}{l}\text { Meningkat 7 } \\
\text { siswa }\end{array}$ \\
\hline $\begin{array}{l}\text { Jumlah siswa yang belum } \\
\text { tuntas }\end{array}$ & 12 siswa & 5 siswa & Turun 7 siswa \\
\hline $\begin{array}{l}\text { Persentase ketuntasan } \\
\text { Nilai rata-rata }\end{array}$ & $68,42 \%$ & $86,84 \%$ & $\begin{array}{l}\text { Meningkat 18,42 } \\
\%\end{array}$ \\
\hline Ketuntasan klasikal & Belum tuntas & Sudah tuntas & \\
\hline
\end{tabular}

Ketuntasan hasil belajar siswa melalu model pembelajaran kooperatif tipe Snowball Throwing memiliki dampak positif dalam meningkatkan hasil belajar siswa yang dapat dilihat dari grafik pencapaian di bawah ini.

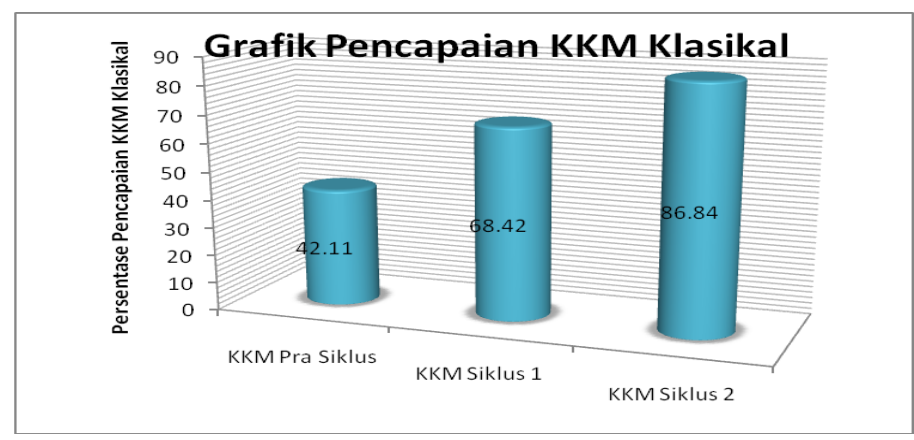

Grafik 1. Pencapaian hasil prasiklus, siklus I, dan siklus II 
Model pembelajaran kooperatif tipe Snowball Throwing memang baik diterapkan untuk mengaktifkan siswa, karena setiap siswa diminta untuk siap dalam menghadapi keadaan. Jika diminta menulis pertanyaan, maka setiap siswa mesti membuat pertanyaan. Jika bola kertas pertanyaan dilemparkan pada grup lain, maka seluruh anggota grup lain harus siap pula menjawab pertanyaan yang mungkin tertuju padanya. Dan pelemparan bola tersebut tidak hanya sekali, tapi berkali-kali sampai waktu belajar berakhir. Tentunya selama pembelajaran berlangsung, setiap siswa dalam kelompoknya berkemungkinan akan mendapat kesempatan. Dengan begitu, mau tidak mau setiap siswa harus belajar untuk menguasai materi yang diajarkan.

Andaikan siswa tidak mampu membuat pertanyaan ataupun menjawab pertanyaan secara mandiri, maka mereka dapat bertanya pada teman sekelompoknya, mereka dapat mendiskusikannya di dalam kelompoknya, dan mereka dapat memutuskannya bersama secara kelompok, walaupun nanti yang diminta menjawab hanya orang-perorang. Dengan demikian, hasil yang dicapai akan lebih baik.

Guru dapat berperan juga membantu menghidupkan suasana belajar dalam permainan lempar bola, guru akan mengarahkan diskusi, membantu kesulitan siswa, dan sekaligus menyimpulkan hasil belajar.

\section{SIMPULAN DAN SARAN}

Dari hasil kegiatan pembelajaran yang telah dilakukan selama dua siklus, dan berdasarkan seluruh pembahasan serta analisis yang telah dilakukan dapat disimpulkan yaitu bahwa pembelajaran dengan model Snowball Throwing memiliki dampak positif dalam meningkatkan hasil belajar siswa yang ditandai dengan peningkatan ketuntasan belajar siswa dalam setiap siklus, yaitu pra siklus $(42,11 \%)$, siklus I $(68,42 \%)$, dan siklus II $(86,84 \%)$.

Dari hasil penelitian yang diperoleh dari uraian sebelumnya agar proses belajar mengajar matematika lebih efektif dan lebih memberikan hasil yang optimal bagi siswa, maka disampaikan saran sebagai berikut: 1) Untuk melaksanakan belajar aktif memerlukan persiapan yang cukup matang, sehingga guru harus mampu menentukan atau memilih topik yang benar-benar bisa diterapkan dengan cara belajar aktif model pembelajaran kooperatif tipe Snowball Throwing sehingga diperoleh hasil maksimal. 2) Perlu adanya penelitian yang lebih lanjut, karena hasil penelitian ini hanya dilakukan di SMA Negeri 18 Palembang.

\section{DAFTAR PUSTAKA}

Hamalik, Oemar, 2007. Manajemen Pengembangan Kurikulum. Bandung: PT. Remaja Rosda Karya.

Hidayanto. 2006. Model-model Pembelajaran Efektif. Jakarta: PT. Bumi Aksara.

Ibrahim, Uslim. 2000. Pembelajaran Kooperatif . Surabaya: Surabaya University Press.

Kemmis, S. and Mc. Taggart, R. 1988. The Action Research Planner. Victoria: Dearcin University Press.

Kunandar. 2013. Langkah Mudah Penelitian Tindakan Kelas Sebagai Pengembangan Profesi Guru . Jakarta: PT. Raja Grafindo Persada.

Mulyasa, E. 2005. Kurikulum Berbasis Kompetensi. Bandung: Remaja Rosdakarya.

Purwanto, N. 2011. Prinsip-prinsip dan Teknis Evaluasi Pengajaran. Bandung: Remaja Rosda Karya. 
Sagala, S. 2010. Konsep dan Makna Pembelajaran. Bandung : Alfabeta.

Sudjana, N. 2009. Penilaian Hasil Proses Belajar Mengajar. Bandung: Remaja Rosdakarya.

Suprijono, A. 2011. Cooperative Learning Teori dan Aplikasi PAIKEM. Yogyakarta: Pusaka Pelajar.

Undang-undang Sistem Pendidikan Nasional (UU Sisdiknas) No. 20 Tahun 2003. Uno. 2007. Profesi Kependidikan. Jakarta: Bumi Aksara. 